advice is supplied to subscribers on any greenkeeping matter, and advisory visits are carried out at standard terms, the large number of requests for advice showing that the work of the Research Station is already widely appreciated. At the same time, it is inevitable that non-subscribing golf clubs are also reaping the benefits of the experience gained at the Station, and the Board urges all unions to consider whether the time has not come when every affiliated club should be required to make an annual minimum contribution to this work for the common good, at a fixed rate according to membership and size or number of their courses. A danger exists that if the present system of purely voluntary subscriptions is maintained, clubs which have supported the work liberally in the past may be unwilling to continue their subscriptions at the same rate, while other clubs obtain similar benefit for a smaller contribution or even contribute nothing at all.

\section{Oxford University Junior Scientific Club}

THE triennial conversazione and exhibition meeting of the Oxford University Junior Scientific Club was held in the University Museum, Oxford, on May 23. An introductory lecture was given by Sir Edward Poulton, formerly Hope professor of zoology and one of the founders of the Club fifty-three years ago. A lecture, illustrated by a number of X-ray films, was given during the evening on "Cineradiology" by Dr. J. Russell Reynolds. A large number of exhibits of scientific interest were demonstrated by undergraduate members of the Club, and much research apparatus was on view. The exhibition was planned to provide both a summary of the progress of fundamental scientific research and a conspectus of the applications of research to modern life. The latter purpose was furthered by the generous assistance of many industrial undertakings, and of the Public Relations Department of the Post Office.

\section{Award of the Albert Medal to Lord Derby}

THE Council of the Royal Society of Arts, with the approval of the president, H.R.H. The Duke of Connaught, has awarded the Albert Medal for 1936 to the Earl of Derby, "for the advancement of Commerce and Arts especially in Lancashire". The Albert Medal, instituted in 1863 as a memorial of H.R.H. the Prince Consort, who for eighteen years was president of the Royal Society of Arts, is awarded for "distinguished merit in promoting Arts, Manufactures and Commerce". The list of past recipients includes the names of many persons of the highest distinction, both in Great Britain and abroad; of the seventy-five awards which have been made, no less than forty-one have been to ordinary fellows and nine to foreign members of the Royal Society. Last year's Albert Medal was awarded to Sir Robert Hadfield.

\section{Linnean Society of London}

Ar the anniversary meeting of the Linnean Society of London held on May 28, the president, Dr. W. T. Calman, delivered his presidential address entitled
"The Origin of Insects". The Linnean Gold Medal was presented to Prof. J. Stanley Gardiner. In making the presentation, the president referred to Prof. Gardiner's researches on the biology of corals, and the origin and development of coral reefs and islands, and also to his services to zoological exploration by means of the many important expeditions which owed their existence to his organising ability, and their success to his enthusiasm and leadership. The following were elected officers for the year 1936-37 : President, Dr. W. T. Calman; Treasurer, Mr. Francis Druce; Secretaries, Mr. John Ramsbottom (botany) and Dr. Stanley Kemp (zoology). The new members of the Council were Captain Cyril Diver, Mr. M. A. C. Hinton, Prof. R. C. MeLean, Mr. Charles Oldham and Dr. Fred Stoker. The president announced that he had appointed the following vicepresidents : Mr. Francis Druce, Dr. John Hutchinson, Dr. Margery Knight and Lieut.-Colonel R. B. Seymour Sewell.

\section{International Congress of Genetics}

THE Seventh International Congress of Geneties will be held in Moscow in the second half of August 1937. Preparations for the Congress have been begun by the Organisation Committee, under the presidency of A. I. Muralov, president of the Lenin Academy of Agricultural Sciences; other members of the Committee are N. I. Vavilov and V. L. Komarov (vice-presidents), S. G. Levit (general secretary), and N. P. Gorbunov, G. D. Karpechenko, B. A. Keller, N. K. Koltzoff, T. D. Lysenko, G. K. Meister, H. J. Muller, M. S. Navashin and A. S. Serebrovsky. All those working in the field of genetics are invited to present contributions. The titles and abstracts should reach the Organisation Committee before February 15, 1937. Detailed information concerning the programme, membership, exhibits, accommodation and transport are being prepared. Excursions to various parts of the U.S.S.R. will form part of the programme. Suggestions and applications for information should be sent to the General Secretary, Organisation Committee, Seventh International Congress of Genetics, B. Kaluzhskaya, 75, Moscow, U.S.S.R.

\section{Working-Class Family Budgets}

IT was announced in the House of Commons on May 28 that the following committee has been appointed to advise the Minister of Labour as to the methods to be adopted in the collection of information, by means of family budgets, showing the approximate average weekly expenditure of working. class families on the items which should be taken into account in the construction of index numbers, designed to measure the percentage changes, from month to month, in the cost of maintaining a present-day standard of living: Mr. F. W. Leggett, Ministry of Labour (chairman); Mr. J. N. Beckett, Ministry of Health; Mr. F. J. Blakemore, past president of the National Chamber of Trade; Prof. A. L. Bowley, professor of statistics, University of London; $\mathrm{Mr}$. H. Crow, Scottish Office; Mrs. W. Y. Darling; Mrs. 